\title{
The hexamethonium asthma study and the death of a normal volunteer in research
}

\author{
J Savulescu, M Spriggs
}

Death of a normal volunteer highlights problems with research review and protection of subjects

Healthy volunteer dies in asthma study

On July 19, after investigating the death of a previously healthy volunteer, the United States Office for Human Research Protections (OHRP) suspended nearly all federally funded medical research involving human subjects at Johns Hopkins University. The death has been described as "particularly disturbing" because 24 year old Ellen Roche was a healthy volunteer who had nothing to gain by taking part in the study. ' Her death has revived debate about the adequacy of oversight of medical research that followed the death of 18 year old Jesse Gelsinger who volunteered for a gene therapy experiment.

$E^{1}$ len Roche was a 24 year old technician from the Johns Hopkins Asthma and Allergy Centre who volunteered to take part in a study designed to provoke a mild asthma attack in order to help doctors discover the reflex that protects the lungs of healthy people against asthma attacks. After inhaling hexamethonium, a medication used for treating high blood pressure in the 1950s and 60s, Ms Roche became ill. She developed a cough and her condition worsened over the next week until she was put on a ventilator. With her lung tissue breaking down, blood pressure falling and her kidneys beginning to fail, nothing could be done to save her. ${ }^{2}$ She died on June 2, about a month after entering the study.

The Office for Human Research Protections (OHRP) investigated the circumstances of Ms Roche's death and accused the Hopkins Institutional Review Board (IRB) of failing to take proper precautions. It also evaluated the human subject protection system at Hopkins. The OHRP found that prior to approving the study, Hopkins researcher Dr Alkis Togias and the Institutional Review Board failed to uncover published literature about the toxic effects of inhaling hexamethonium. According to the OHRP, this information was "readily available via routine MEDLINE and Internet database searches, as well as recent textbooks on pathology of the lung". ${ }^{3}$ Togias had performed a standard PubMed search and consulted standard, current edition, textbooks which produced four publications relating to similar studies. ${ }^{4}$ But these publications did not mention the 1950s era reports of toxicity and Togias failed to look up the 1950s medical journals. ${ }^{5}$ The Hopkins review board neither requested nor searched for additional safety data beyond what was provided. In a letter to the OHRP, Hopkins officials said that the IRB "relied on the information submitted by the investigator who was known to them as an experienced researcher". ${ }^{4}$ And in a letter to the Food and Drug Administration, Daniel Kracov, Togias's attorney, claimed Togias was relying on the Hopkins review board to guide him on whether to seek approval from the FDA before using the substance. ${ }^{6}$

A federal investigation also found that the study was not reviewed at a properly convened meeting and volunteers were not warned of the risks. The informed consent document referred to hexamethonium as a "medication" and did not mention the fact that hexamethonium used by inhalation was experimental. Hexamethonium was withdrawn from human use by the Food and Drug Administration (FDA) in the 1970s and had "never been approved by the FDA for administration via inhalation". ${ }^{8}$ And finally, Togias failed to report the cough, shortness of breath, and decreased lung function experienced by an earlier subject in the study. ${ }^{7}$ Instead of doing more research on the toxicity of the substance, Togias decided the volunteer had caught a cold. ${ }^{9}$

In its evaluation of the human subject protection system at Hopkins, the OHRP found that the IRB was failing to properly review research. Most protocols were not individually presented or discussed at convened or properly constituted meetings. Research must be reviewed at a convened meeting including at least one member whose primary concerns are nonscientific areas and where a majority of members are present. ${ }^{10}$ The
OHRP did not regard the executive subcommittee review process relied on at Johns Hopkins as "substantive and meaningful IRB review". ${ }^{11}$ The Hopkins IRB was also criticised for not keeping proper documentation to show attendance at meetings and to show that research was reviewed according to the correct procedures. There were no minutes for 18 of the last 21 meetings of the Hopkins IRB. The OHRP also concluded that a lack of diversity in the current membership of the IRB meant that it might not promote respect for its advice and counsel in safeguarding the rights and welfare of human subjects as required by the regulations. ${ }^{12}$

Hopkins officials responded to the OHRP research suspension with outrage. They claimed the action was "unwarranted, unnecessary, paralyzing, and precipitous" and "an extreme example of regulatory excess". The university also said that tens of thousands of people had taken part in its medical research and Ms Roche was the only one who had died. ${ }^{13}$

On July 22, the OHRP authorised Hopkins to resume research involving "minimal risk" but studies in which there is "greater than a minimal risk" to subjects remain suspended and must be "re-reviewed". ${ }^{14}$ In order to resume research the university was ordered to take specific action. It had to restructure its system for protecting subjects with "an enhanced institutional commitment to human subject protections" and develop a plan to make sure the ethics committee and researchers are educated about the requirements for protecting human subjects. ${ }^{15}$

The death of Ms Roche highlights problems with the review of research and the protection of subjects. There is a problem with researchers not bothering to properly research the literature and assuming that everything will be available on the internet. According to Dr Frederick Wolff, a professor emeritus at the George Washington School of Medicine, it was "foolish" and "lazy" that the investigator and the Hopkins review board failed to look up the 1950s medical journal articles warning of lung damage caused by inhaling hexamethonium. "Anyone trained in academic medicine knows how to do this research," he said. $^{5}$ 
Another problem brought to light is adverse events that are not reported and not published. In a similar study using hexamethonium in 1978, two healthy volunteers suffered adverse reactions but these problems were not included in the published study because researchers conducting the experiment did not think they were related to the drug. This was one of the four studies Dr Togias used as evidence that inhaling hexamethonium was safe. ${ }^{16}$ What is more, the four studies included only 20 patients and according to the report of an internal panel investigating the death at Hopkins the study should never have been approved: "Small clinical trials give uncertain estimates for even frequent adverse events, and may miss even relatively common toxicity." ${ }^{\prime \prime}$

The circumstances of Ms Roche's enrolment in the study have also been criticised. Because she was an employee at Hopkins there is a potential for coercion or consent under duress. ${ }^{17}$ And although Ms Roche has been described as a volunteer her name was in fact obtained from a registry of people who had participated in past studies. A doctor called her to ask if she wanted to take part. $^{5}$

Dr Sidney Wolfe, of the Public Citizen Health Research Group said that "if protections are flawed at esteemed places such as Hopkins, they are likely flawed elsewhere" ${ }^{18}$ According to bioethicist Arthur Caplan, the United States system for protecting human subjects "is not simply sick-it is dead". Johns Hopkins is not the culprit, he claims. It is "an indictment of our societal failure to attend seriously to a crisis that has been building for years ..."'19 Michael A Susko, president of Citizens for Responsible Care and Research (CIRCARE) argues for independent review boards made up of people not employed by the research institutions. He claims that IRBs do not provide "truly independent review" because employees "tend to have a vested interest in not running up against their employer". ${ }^{17}$

\section{EDITOR'S NOTE}

You can respond to this piece by writing an eletter. Log on to our website (www.jmedethics.com), find this paper, click on "full text" and send your response by email by clicking on "submit a response".

J Med Ethics 2002;28:3-4

\section{Authors' affiliations}

J Savulescu, Ethics Program, The Murdoch Childrens Research Institute, Royal Children's Hospital, Flemington Road, Parkville, Melbourne, Victoria 3052, Australia; savulesj@cryptic.rch.unimelb.edu.au M Spriggs, Ethics Program, The Murdoch Childrens Research Institute, Royal Children's Hospital, Flemington Road, Parkville, Melbourne, Victoria 3052, Australia; spriggsm@murdoch.rch.unimelb.edu.au

\section{REFERENCES}

1 Josefson D. Healthy woman dies in research experiment. British Medical Journal 2001;322:1565.

$2{ }^{*}$ Mills A. Human testing alarm raised. National Post Online. Accessed at www.nationalpost.com Jul 302001

3 Office for Human Subject Protection (OHRP). Suspension letter to Johns Hopkins University 2001 Jul 19: 2. http:// ohrp.osophs.dhhs.gov/detrm_letrs/ july0 la.pdf

4 Johns Hopkins letter to OHRP 2001 Jul 17. 1.http://www.hopkinsmedicine.org/ press/2001/JULY/letter_to_OHRP.htm

5 EBor J, Pelton T. Hopkins faults safety lapses. The Baltimore Sun 2001 Jul 17.

http://www.med.jhu.edu/bioethics_institute/

6 Togias A. Letter to the FDA 2001 Jul 16. http://www.med.jhu.edu/bioethics_institute/; See also reference 5

7 See reference 3: 4

8 See reference $3: 2$.

9 Johns Hopkins University. Report of internal investigation into the death of a volunteer research subject. $2001 \mathrm{Jul} \mathrm{http://}$ www.hopkinsmedicine.org/press/2001/ JULY/report_of_internal_investigation.htm

10 See Reference 3: 5

11 Office for Human Subject Protection (OHRP). Response to corrective action plan 2001 Jul 22: 4. http:// ohrp.osophs.dhhs.gov/detrm_letrs/jul01b.pdf
12 See reference 3: 6-8.

13 Johns Hopkins letter of response to OHRP Suspension of Research $2001 \mathrm{Jul} 19$. http://www.med.jhu.edu/bioethics_institute/

14 Hopkins to resume federal clinical trials. MSNBC 2001 Jul 23 quoting OHRP spokesman Bill Hall. http://www.msnbc.com/ news/602568.asp

15 See reference 3: 10

16 Glanz J. 1978 study had troubles like a fatal Hopkins test. The New York Times 2001 Jul 26. http://www.med.jhu.edu/ bioethics_institute/

17 Susko M. Researchers must ensure woman didn't die in vain. The Baltimore Sun $2001 \mathrm{Jul}$ 25. http://www.med.jhu.edu/

bioethics_institute/; see also section 23 of World Medical Association. Declaration of Helsinki http://www.wma.net/e/policy/ 17-c e.html

18 *Bor J, Stroh M. Hopkins bruised, unbroken. The Baltimore Sun 2001 Jul 26. http://www. sunspot.net/

19 Caplan A. Research ban at Hopkins a sign of ethical crisis. MSNBC 2001 Jul 20 http://www.med.jhu.edu/bioethics_institute/

\section{ADDITIONAL REFERENCES}

Josefson D. US researchers guilty of breaking safety rules. British Medical Journal 2001;323:69.

Kolata G. US suspends human research at Johns Hopkins after a death. The New York Times 2001 Jul 20.

Ramsay S. Johns Hopkins takes responsibility for volunteer's death. The Lancet 2001;358:213.

*Riley M. Drug trials suspended after young researcher turns guinea pig with fatal results. Sydney Morning Herald. Accessed at 2001 Jul 21.

Wadman M. Johns Hopkins researchers fume over government crackdown. Nature 2001;26:363.

*copy available from authors

\section{LINKS}

British Medical Journal

http://bmj.com/

Food and Drug Administration, US Department

of Health and Human Services.

http://www.fda.gov/

Johns Hopkins Medicine: research volunteer death (documents related to the death and the investigation)

http://www.hopkinsmedicine.org/

researchvolunteerdeath.html

Johns Hopkins Research (newspaper articles related to the research volunteer death and investigation)

http://www.med.jhu.edu/bioethics_institute/

Office for Human Research Protections, US

Department of Health and Human Services

http://ohrp.osophs.dhhs.gov/index.htm

World Medical Association, Declaration of Helsinki. http://www.wma.net/e/policy/17-c_e.html 